\title{
The effect of Myrtus communis oil extract on growth performance, serum biochemistry and humoral immune responses in broiler chicks fed diet containing aflatoxin B1
}

\author{
Mohsen Mohamadi Saei', Ali Asghar Sadeghi' and Hasan Ahmadvand ${ }^{2}$ \\ 'Department of Animal Science, Science and Research Branch, Islamic Azad University, Tehran, Iran, ${ }^{2}$ Department of \\ Biochemistry, Faculty of Medicine, Lorestan University of Medical Sciences, Khorramabad, Iran
}

\begin{abstract}
The study was conducted to investigate the capability of Myrtus communis essential oil (MCE) in counteracting the deleterious effects of aflatoxin B1 (AFB1) on growth performance, serum biochemistry and humoral immune responses in broiler chickens. In a completely randomized design, 300 day-old male chickens were assigned to four treatments with five replicates of 15 birds for 42 days. Chickens, up to day seven of age, were fed the same diet and then, they were fed the experimental diets. The dietary treatments were 1) the negative control (no dietary aflatoxin or MCE), 2) the positive control (diet containing AFB1 at $0.5 \mathrm{mg} / \mathrm{kg}$, without $M(E)$, 3) diet containing AFB1 at $0.5 \mathrm{mg} / \mathrm{kg}$ plus $500 \mathrm{mg} / \mathrm{kg} \mathrm{MCE}$, and 4) basal diet containing $500 \mathrm{mg} / \mathrm{kg} \mathrm{MCE}$, without AFB1. Growth performance was measured from day seven to 42 . Serum biochemical parameters, organ weights on day 42 and the antibody titres against Newcastle and influenza viruses on day 28 of age were determined. Addition of aflatoxin to diet decreased $(P<0.05)$ the weight gain and feed intake and MCE supplementation diminished $(P<0.05)$ the inhibitory effects of AFB1 on the growth performance. Addition of AFB1 to diet of chicks increased the serum activities of aspartate aminotransferase, alkaline aminotransferase, alkaline phosphatase, and decreased the antibody titres against Newcastle and influenza viruses. Addition of MCE to diet alleviated the negative effects of AFB1 on these parameters $(P<0.05)$. In conclusion, our results showed that addition of MCE may reduce the adverse effects of AFB1 on broiler chickens.
\end{abstract}


Keywords: aflatoxin, Myrtus communis, performance, serum biochemistry, broiler chicken

Abbreviations: AFB1: aflatoxin B1; AIV: Avian Influenza virus; ALP: alkaline phosphatase; ALT: alkaline aminotransferase; AST: aspartate aminotransferase; FCR: feed conversion ratio; GGT: gammaglutamyltransferase; GLM: general linear model; hemagglutination inhibition; MCE: Myrtus communis essential oil; NDV: Newcastle Disease virus

\section{Introduction}

Aflatoxins are a group of mycotoxins produced by the strains of Aspergillus flavus and Aspergillus parasiticus in the feedstuffs (Bennett \& Klich 2003). While there are a number of aflatoxins such as B1, B2, G1, G2, aflatoxin B1 is the most prevalent, and highly hepatotoxic and carcinogenic in both human and animals (Wild \& Turner 2002, Williams et al. 2004). These fungi infect crops such as corn, cottonseed, peanut, rice, soybean, tree nuts as well as products derived from them causing both important economic losses and health problems (Etcheverry et al. 1999). The fungi invade grains/seeds at pre-harvest stage in the field, during post-harvest drying/curing and storage and produce aflatoxins. These aflatoxins are extremely durable under most conditions of storage, handling and processing of foods or feeds.

Detoxification of aflatoxins appears to be a more attractive approach. Several strategies for the detoxification of aflatoxins by physical, chemical and biological means have been reported (Harvey et al. 1989). However, each treatment has its own limitations, since the treated product should be safe and unaffected by the chemicals used and the nutritive values of the treated product should not be altered. Natural plant products are of interest as a source of safer or more effective substitutes for synthetic antimicrobial agents and may provide an alternative way to prevent food or feed from fungal or aflatoxin contamination. Powders and extracts of many medicinal herbs have been reported to inhibit the growth of A. flavus and production of aflatoxin (Sandosskumar et al. 2007, Krishnamurthy \& Shashikala 2006).

Myrtus communis L. (Myrtaceae) is an evergreen scrub, typical of the Mediterranean maquis, which grows spontaneously in many countries. It is traditionally used as an antiseptic, disinfectant drug and hypoglycaemic agent (Elfellah et al. 1984). On the chemical composition of the essential oil of the plant has been reported (Bradesi et al. 1997). On the antioxidant activity of myrtle liquor was reported by Alamanni \& Cossu (2004). The presence of phenolic compounds (phenolic acids, polyphenols and flavonoids) in herbs and spices of this plant, along with the essential oils, is gaining increasing attention because of their various functions, such as antioxidant activity and flavouring properties (Issa et al. 2006).

In the literature, there was no report concerning the effect of dietary essential oil of Myrtus communis on performance, serum biochemistry and immune responses of broilers exposed to aflatoxin. Therefore, this study was conducted to evaluate the potential of applying extract of MCE on performance, the antibody titres against Newcastle and Influenza viruses and serum biochemistry in broiler chicks fed diets containing aflatoxin B1. 


\section{Materials and methods}

\section{Aflatoxin production}

The aflatoxin production was performed by the inoculation of the strain of Aspergillus parasiticus (PTTS 5286) on rice as described by Shotwell et al. (1966). The sterile substrate, placed in Erlenmeyer flasks, was inoculated with $2 \mathrm{ml}$ of the mold aqueous suspension containing $10^{6}$ spores per $\mathrm{ml}$. Cultures were allowed to grow for seven days at $39^{\circ} \mathrm{C}$ in darkness. On the seventh day, Erlenmeyer flasks were autoclaved; culture material was dried for $48 \mathrm{~h}$ at $40^{\circ} \mathrm{C}$ in a forced-air oven and ground to a fine powder. The AFB1 levels in rice powder were measured by HPLC method (AOAC 1995). The milled substrate was added to the basal diet (Table 1) to provide the level of $0.5 \mathrm{mg} / \mathrm{kg}$ of AFB1.

Table 1

The ingredient and calculated composition of basal starter, grower, and finisher diets

\begin{tabular}{lccc}
\hline Item & Starter & Grower & Finisher \\
\hline Ingredient, $\mathrm{g} / \mathrm{kg}$ & & & \\
Corn & 537.3 & 518 & 556 \\
Soybean mea & 400 & 375 & 370 \\
Soybean oil & 20 & 35 & 35 \\
Di calcium phosphate & 19.3 & 17.7 & 15.6 \\
CaCO & 10.5 & 8.8 & 8.5 \\
NaCl & 3.5 & 3 & 3 \\
Trace mineral premix & 2.5 & 2.5 \\
Vitamin premix & 2.5 & 2.5 & 2.5 \\
DL-methionine & 2.5 & 2.5 & 1.4 \\
L-lysine & 3.1 & 2 & - \\
Myrtus communis oil extract & 1.3 & - & 0.5 \\
Rice powder containing aflatoxin & - & 0.5 & 25 \\
Calculated composition & - & 25 & 3000 \\
Metabolizable energy, kcal/kg & 2870 & & 210 \\
Crude protein, g/kg & 221 & 2980 & 7 \\
Calcium, g/kg & 8.6 & 220 & 4.1 \\
Available phosphorus, g/kg & 4.9 & 7.5 & 8 \\
Methionine+cysteine, $\mathrm{g} / \mathrm{kg}$ & 1.1 & 4.4 & 11.3 \\
Lysine, g/kg & 13.3 & 8.9 & 6.3 \\
Threonine, g/kg & 8.3 & 11.9 & 3 \\
Tryptophan, g/kg & 3.2 & 8.3 & 3.2 \\
\hline
\end{tabular}

aProvided the following per $\mathrm{kg}$ of diet: $\mathrm{Mg}, 56 \mathrm{mg} ; \mathrm{Fe}, 20 \mathrm{mg} ; \mathrm{Cu}, 10 \mathrm{mg} ; \mathrm{Zn}, 50 \mathrm{mg} ; \mathrm{Co}, 125 \mathrm{mg}$; I, $0.8 \mathrm{mg} ;{ }^{b}$ Provided the following per kg of diet: vitamin A, 10,000 IU; vitamin D3, $2000 \mathrm{IU}$; vitamin E, $5 \mathrm{IU}$; vitamin $\mathrm{K}, 2 \mathrm{mg}$; riboflavin, $4.20 \mathrm{mg}$; vitamin B12, $0.01 \mathrm{mg}$; pantothenic acid, $5 \mathrm{mg}$; nicotinic acid, $20 \mathrm{mg}$; folic acid, $0.5 \mathrm{mg}$; choline, $3 \mathrm{mg}$

\section{Animals and dietary treatments}

A total of 300 day-old male broiler chicks (Ross 308) were purchased from a local hatchery. Chickens up to day seven of age were fed the same starter diet based on corn and soybean meal. Thereafter, birds were fed the experimental diets until day 42 of age. On day eight of age, the birds were weighed and randomly allocated to one of the four treatments with five replicates of 15 birds in a completely randomized design. The dietary treatments were 1) the 
negative control (no dietary aflatoxin or MCE), 2) the positive control (diet containing AFB1 at $0.5 \mathrm{mg} / \mathrm{kg}$, without MCE), 3) basal diet containing $500 \mathrm{mg} / \mathrm{kg} \mathrm{MCE}$, without AFB1, and 4) diet containing AFB1 at $0.5 \mathrm{mg} / \mathrm{kg}$ plus $500 \mathrm{mg} / \mathrm{kg}$ MCE. The basal diet formulated to meet the nutrient requirements of broilers has been shown in Table 1. Chicks were raised on floor pens $(150 \times 150 \times 80 \mathrm{~cm})$ for six weeks and had free access to feed and water throughout the entire experimental period. The lighting program consisted of a period of $23 \mathrm{~h} \mathrm{light}$ and one $\mathrm{h}$ of darkness. The ambient temperature was gradually decreased from 33 to $25^{\circ} \mathrm{C}$ on day 21 and was then kept constant.

\section{Performance and organ weights}

The body weight was determined at days 14,28 and 42 of age. Feed consumption and weight gain were recorded at mentioned periods and feed conversion ratio (FCR) was calculated. At day 42 of age, two birds of each replicate were randomly chosen based on the average weight of the group and sacrificed. Carcass yield was calculated by dividing eviscerated weight by live weight. Abdominal fat, liver and pancreas were separated, weighed and the relative weight was calculated as a percentage of live body weight.

\section{Vaccination and immunological tests}

The commercially available oil-adjuvant injectable emulsion against Newcastle Disease virus (NDV) and Avian Influenza virus (AIV, H9N2 subtype) were used for vaccinating broiler chicks. Vaccines were injected subcutaneously with $0.2 \mathrm{ml}$ per chick at day nine of age. Also, chicks were orally vaccinated against Newcastle Disease (Lasota) at day 21 of age. At day 28 of age, two chicks from each pen were randomly selected and blood samples were taken by puncture of the brachial vein for analysis of antibody titres against NDV and AIV. Serum antibody titres against NDV and AIV were measured by the hemagglutination inhibition (HI) test, and $\mathrm{HI}$ antibodies were then converted to log2.

\section{Serum biochemical parameters}

After $12 \mathrm{~h}$ fasting, blood samples were collected in the tubes without anticoagulant at day 42 of age from two birds in each pen by puncturing the brachial vein and the blood was centrifuged to obtain serum. Individual serum samples were analysed for aspartate aminotransferase (AST), alkaline aminotransferase (ALT), alkaline phosphatase (ALP), gammaglutamyltransferase (GGT), total protein, triglyceride, cholesterol, blood urea nitrogen and creatinine were determined using an automated analyser (Technicon RA-1000, Luton, United Kingdom) according to the commercial kit protocol (Pars Azmoon Company; Tehran, Iran).

\section{Statistical analysis}

All values were analysed by one-way ANOVA using the GLM procedure of SAS for Windows version 9.1 (SAS Institute Inc., Cary, NC). When the F-test for treatments was significant at $P \leq 0.05$ in the ANOVA table, means were compared for significant differences using the Duncan's multiple range tests of SAS. 


\section{Results}

\section{Performance}

Effects of treatments on the performance of broilers at different periods are shown in Table 2. In the different periods, the lowest weight gain and feed intake and the highest FCR were found in the positive control group and the addition of MCE to contaminated diet improved these parameters compared with the positive control. In the total of period, birds fed diets containing aflatoxin had lower body weight and feed intake compared with the negative control group. Feed conversion ratio of chickens fed diets containing aflatoxin was poorer $(P<0.05)$ than in the other groups. Addition of MCE to contaminated diet increased body weight gain and feed intake and FCR compared with the group fed the positive control diet. Feed conversion ratio was better $(P<0.05)$ in the birds fed MCE alone compared with the negative control group.

Table 2

Effect of experimental diets on performance indices of broilers at different ages

\begin{tabular}{lccccc}
\hline Variable & \multicolumn{5}{c}{ Dietary treatment } \\
& Negative control & Positive control & MCE & MCE+AFB1 & SEM \\
\hline BW gain, g & & & & & \\
$0-14$ & $288^{\mathrm{a}}$ & $247^{\mathrm{d}}$ & $271^{\mathrm{b}}$ & $258^{\mathrm{c}}$ & 3.05 \\
$15-28$ & $857^{\mathrm{a}}$ & $652^{\mathrm{b}}$ & $823^{\mathrm{a}}$ & $817^{\mathrm{a}}$ & 19.23 \\
$29-42$ & $1030^{\mathrm{a}}$ & $859^{\mathrm{b}}$ & $1061^{\mathrm{a}}$ & $970^{\mathrm{ab}}$ & 20.45 \\
Total period & $2176^{\mathrm{a}}$ & $1753^{\mathrm{c}}$ & $2139^{\mathrm{ab}}$ & $2039^{\mathrm{b}}$ & 40.21 \\
Feed intake, & & & & & \\
$0-14$ & $436^{\mathrm{a}}$ & $379^{\mathrm{c}}$ & $401^{\mathrm{b}}$ & $388^{\mathrm{bc}}$ & 3.95 \\
$15-28$ & $1506^{\mathrm{a}}$ & $1231^{\mathrm{c}}$ & $1374^{\mathrm{b}}$ & $1400^{\mathrm{b}}$ & 25.29 \\
$29-42$ & $2237^{\mathrm{a}}$ & $1869^{\mathrm{c}}$ & $2068^{\mathrm{b}}$ & $1989^{\mathrm{bc}}$ & 37.82 \\
Total period & $4157^{\mathrm{a}}$ & $3485^{\mathrm{c}}$ & $3803^{\mathrm{b}}$ & $3741^{\mathrm{b}}$ & 62.30 \\
Feed conversion ratio & & & & & \\
$0-14$ & 1.51 & 1.54 & 1.48 & 1.51 & 0.01 \\
$15-28$ & $1.76^{\mathrm{b}}$ & $1.92^{\mathrm{a}}$ & $1.67^{\mathrm{b}}$ & $1.71^{\mathrm{b}}$ & 0.02 \\
$29-42$ & 2.19 & 2.20 & 1.95 & 2.12 & 0.02 \\
Total period & $1.92^{\mathrm{b}}$ & $1.99^{\mathrm{a}}$ & $1.78^{\mathrm{d}}$ & $1.84^{\mathrm{c}}$ & 0.01 \\
\hline
\end{tabular}

$\mathrm{a}, \mathrm{b}, \mathrm{c}$ Values in the same row not sharing a common superscript differ $(P<0.05)$.

\section{Serum biochemical parameters}

The effects of treatments on blood biochemical parameters of broilers at day 42 of age are shown in Table 3. There was no significant difference for total protein and GGT among treatments $(P>0.05)$. However, significant differences were observed for other serum biochemical parameters. The maximum levels of glucose and albumin were found in the negative control group and showed a significant difference in comparison with other groups. Feeding diets containing aflatoxin reduced the levels of glucose and albumin in serum. Addition of MCE to contaminated diet increased the serum albumin level, but decreased further the level of glucose. 
Table 3

Effect of experimental diets on serum biochemical parameters of broilers at day 42 of age

\begin{tabular}{lccccc}
\hline Variable & \multicolumn{5}{c}{ Dietary treatment } \\
& Negative control & Positive control & MCE & MCE+AFB1 & SEM \\
\hline Glucose, $\mathrm{mg} / \mathrm{dL}$ & $243^{\mathrm{a}}$ & $219^{\mathrm{b}}$ & $200^{\mathrm{c}}$ & $190^{\mathrm{c}}$ & 2.98 \\
Creatinine, $\mu \mathrm{mol} / \mathrm{L}$ & $0.32^{\mathrm{ab}}$ & $0.35^{\mathrm{a}}$ & $0.30^{\mathrm{b}}$ & $0.33^{\mathrm{ab}}$ & 0.06 \\
Cholesterol, $\mathrm{mg} / \mathrm{dL}$ & $135^{\mathrm{a}}$ & $126^{\mathrm{ab}}$ & $123^{\mathrm{b}}$ & $122^{\mathrm{b}}$ & 2.55 \\
Triglyceride, $\mathrm{mg} / \mathrm{dL}$ & $61.83^{\mathrm{a}}$ & $54.67^{\mathrm{ab}}$ & $49.17^{\mathrm{b}}$ & $46.67^{\mathrm{b}}$ & 1.21 \\
Total protein, $\mathrm{g} / \mathrm{dL}$ & 4.13 & 3.8 & 3.87 & 4.17 & 0.09 \\
Albumin, $\mathrm{g} / \mathrm{dL}$ & $2.52^{\mathrm{a}}$ & $2.32^{\mathrm{c}}$ & $2.43^{\mathrm{ab}}$ & $2.40^{\mathrm{bc}}$ & 0.03 \\
AST, U/L & $349^{\mathrm{b}}$ & $387^{\mathrm{a}}$ & $352^{\mathrm{b}}$ & $361^{\mathrm{ab}}$ & 7.07 \\
ALT, U/L & $4.01^{\mathrm{b}}$ & $5.33^{\mathrm{a}}$ & $4.33^{\mathrm{ab}}$ & $4.67^{\mathrm{ab}}$ & 0.17 \\
ALP, U/L & $3857^{\mathrm{b}}$ & $4579^{\mathrm{a}}$ & $4128^{\mathrm{b}}$ & $4317^{\mathrm{ab}}$ & 152 \\
GGT, U/L & 21.01 & 22.50 & 20.67 & 21.5 & 0.54 \\
\hline
\end{tabular}

${ }^{a, b}$ Means in the same row without a common superscript differ $(P<0.05)$.

Highest level of creatinine was observed in birds fed diet containing aflatoxin and inclusion of MCE in diet containing aflatoxin decreased it. The lowest level of creatinine was observed in the birds fed diet containing MCE alone. The highest level of cholesterol and triglycerides were observed in the negative control and positive control and the lowest ones in birds fed diet containing MCE.

Feeding of the broilers with the diet containing aflatoxin (positive control) increased the levels of AST, ALT and ALP in the serum compared with the negative control group. By addition of MCE to the diet containing aflatoxin, the serum levels of these enzymes decreased numerically compared with the positive control.

\section{Relative organ weights}

Relative weights of organs are shown in Table 4. The relative weights of liver and spleen were significantly different among treatments $(P<0.05)$. Maximum relative weight of liver was obtained in the birds fed diet containing aflatoxin, which was different compared with negative control group. Also, maximum relative weight of spleen was obtained in the birds fed diet containing aflatoxin. Addition of MCE to diet containing aflatoxin decreased the effects of aflatoxin on the relative liver and spleen weights. Moreover, the relative weight of liver and spleen in the birds fed MCE alone was not different compared to the negative control group $(P>0.05)$. There were no differences among treatments for the relative weight of abdominal fat and pancreas.

Table 4

Effect of experimental diets on the relative weight of some organs at day 42 of age

\begin{tabular}{lccccc}
\hline & \multicolumn{5}{c}{ Dietary treatment } \\
& Negative control & Positive control & MCE & MCE+AFB1 & SEM \\
\hline Abdominal fat weight, \% BW & 1.41 & 1.31 & 1.18 & 1.28 & 0.05 \\
Liver weight, \% BW & $2.10^{\mathrm{b}}$ & $2.49^{\mathrm{a}}$ & $2.05^{\mathrm{b}}$ & $2.33^{\mathrm{ab}}$ & 0.07 \\
Spleen weight, \% BW & $0.11^{\mathrm{ab}}$ & $0.14^{\mathrm{a}}$ & $0.11^{\mathrm{b}}$ & $0.12^{\mathrm{b}}$ & 0.01 \\
Pancreas weight, \% BW & 0.25 & 0.27 & 0.23 & 0.21 & 0.02 \\
\hline
\end{tabular}

BW: body weight, a,b Means in the same row without a common superscript differ $(P<0.05)$. 


\section{Antibody titre}

The effects of experimental diets on antibody titres against Newcastle and Influenza viruses at day 28 of age are presented in Table 5 . Antibody titre against NDV and AIV was significantly different between treatments $(P<0.05)$. The lowest antibody titre against NDV was observed in birds fed diets containing aflatoxin and the addition of MCE to contaminated diet increased antibody titres against NDV significantly. The highest titre of antibody against AIV was found in birds fed diet containing MCE alone, which showed significant difference with other groups.

Table 5

Effect of experimental diets on antibody titres against Newcastle and Influenza viruses at day 28 of age

\begin{tabular}{|c|c|c|c|c|c|}
\hline \multirow[t]{2}{*}{ Variable } & \multicolumn{5}{|c|}{ Dietary treatment } \\
\hline & Negative contro & Positive control & MCE & $\mathrm{MCE}+\mathrm{AFB} 1$ & SEM \\
\hline New castle (log2) & $7^{a}$ & $5^{b}$ & $7.2^{\mathrm{a}}$ & $7.1^{\mathrm{a}}$ & 0.19 \\
\hline Influenza (log2) & $5^{b}$ & $5^{\mathrm{b}}$ & $6^{a}$ & $5^{\mathrm{b}}$ & 0.15 \\
\hline
\end{tabular}

a,b Values in the same row not sharing a common superscript differ $(P<0.05)$.

\section{Discussion}

The most important effect of aflatoxin on poultry is a decrease in growth rate. The results of this study indicated that inclusion of aflatoxin at dose of $0.5 \mathrm{mg} / \mathrm{kg}$ in diet severely affected the performance of broiler chickens. Our finding is consisted with the report of Dorner et al. (1983), in which dietary aflatoxins resulted in a significant decrease in feed intake and body weight gain and consequently poor feed conversion ratio. In another study Denli et al. (2004) reported that by the inclusion of aflatoxins in diets of broiler chicks, the rate of daily gain decreased. The reduced feed intake due to aflatoxin ingestion may contribute to protein catabolism, increase of blood ammonia, kidney injury and impairment of glomerular filtration (Tessari et al. 2006). Moreover, the adverse effects of aflatoxins on growth performance have been related to a decrease in the protein and energy utilization (Verma et al. 2002), probably as a consequence of a deterioration of the digestive and metabolic efficiency of the birds. The inclusion of MCE in the diet containing aflatoxin affected the performance and led to a reduction in the negative effects of aflatoxin. In the literature, there was no information regarding the effect of $M C E$ on performance of broiler chickens exposed to dietary aflatoxin.

Serum AST, ALT and ALP are the most sensitive markers used in the diagnosis of hepatic damage, because they are cytoplasmic enzymes and are released into the circulation after cellular damage. Increase in the level of these enzymes due to the dietary aflatoxin B1 has been reported by Dafalla et al. (1987), which corresponded with the results of this study. In contrast, Edrington et al. (1997) did not observe changes in the levels of these enzymes by addition of aflatoxin to the diet. By addition of MCE to diet containing aflatoxin, levels of ALT, AST and ALP decreased. It is likely that the phenolic compounds present in MCE protected the liver against toxic agents.

In the present study, the birds fed diets containing aflatoxin compared with the control group had the lowest concentration of glucose, cholesterol, triglycerides and total protein. These results were consistent with the findings of previous studies (Jansen van Rensburg et 
al. 2006, Allameh et al. 2005). Decline in the levels of cholesterol and triglycerides in broiler chickens fed diets contaminated with aflatoxins have also been reported by Fernandez et al. (1994) . The reduction in total protein levels due to dietary aflatoxin inclusion may result from a defect in the transport of amino acids and mRNA transcription. Defect in the mRNA transcription results from the inhibition of DNA-dependent RNA polymerase by aflatoxin. Thus, the synthesis of DNA and protein is prevented in the body of birds fed aflatoxin (Marquardt et al. 1992), which is reflected as reduction in serum total protein.

In our study the relative weight of liver of birds fed dietary aflatoxin increased significantly. It is possible that more detoxification process and more fat accumulation in the liver are the main causes of increased liver weight. Significant increase in the relative weight of spleen in broilers fed diet contaminated with aflatoxin has been reported by Bailey et al. (2006). Increase in the relative weight of spleen can be attributed to the overactivity of spleen during feeding diet containing aflatoxins. The effect of aflatoxin on the relative weight of liver and spleen was reduced by addition of MCE to diet. In consistence with the present study, Mousavizadeh et al. (2011) reported that the powder of Myrtus communis in the chickens fed acidified diets could reduce the abdominal fat and relative weight of liver.

Serum antibody titre against NDV was the highest in birds fed MCE alone and the lowest in birds fed diet containing aflatoxin. It is clear that aflatoxin caused severe immuno-suppression due to reduction in phagocytic activity of blood monocytes, depressed complement activity, and hence depressed opsonisation and phagocytic activity (Tessari et al. 2006).

In summary, these results suggest that treatment with MCE decreases the toxic severity of aflatoxin on serum glucose, creatinine, cholesterol, ALT, AST, ALP concentration, feed intake, and body weight gain in broilers. The protective action of this compound was particularly evident in growth performance. These findings suggest that MCE might be used in chickens to prevent the effects of aflatoxins in contaminated feed and provide a basis for further studies on the relationship between MCE and protection against aflatoxins toxicity, to improve health, safety and quality of poultry products.

\section{References}

Alamanni MC, Cossu M (2007) Radical scavenging activity and antioxidant activity of liquors of myrtle (Myrtus communis L.) berries and leaves. Ital J Food Sci 16, 197-208

Allameh A, Safamehr A, Mirhadi SA, Shivazad M, Razzaghi-Abyaneh M, Afshar-Naderi A (2005) Evaluation of biochemical and production parameters of broiler chicks fed ammonia treated aflatoxin contaminated maize grains. Anim Feed Sci Technol 122, 289-301

AOAC (1995) Official Methods of Analysis, 16th Edition, Association of Official Analytical Chemists, Gaitherburg, MD, USA

Bailey CA, Latimer GW, Barr AC, Wigle WL, Haq AU, Balthrop JE, Kubena LF (2006) Efficacy of Montmorillonite Clay (NovaSil PLUS) for Protecting Full-Term Broilers from Aflatoxicosis. J Appl Poult Res 15, 198-206

Bennett JW, Klich M (2003) Mycotoxins. Clin Microbiol Rev 16, 497-516

Bradesi P, Tomi F, Casanova J, Costa J, Bernardini AF (1997) Chemical Composition of Myrtle Leaf Essential Oil from Corsica (France). J Essent Oil Res 9, 283-288

Dafalla R, Yagi Al, Adam SE (1987) Experimental aflatoxicosis in hybro-type chicks: sequential changes in growth and serum constituents and histopathological changes. Vet Hum Toxicol 29, 222-226 
Denli M, Okan F, Uluocak AM (2004) Effect of dietary supplementation of herb essential oils on the growth performance, carcass and intestinal characteristics of quail (Coturnix coturnix japonica). South Afr J Anim Sci 34, 174-179

Dorner JW, Cole RJ, Lomax LG, Gosser HS, Diener UL (1983) Cyclopiazonic acid production by Aspergillus flavus and its effects on broiler chickens. Appl Environ Microbiol 46, 698-703

Edrington TS, Kubena LF, Harvey RB, Rottinghaus GE (1997) Influence of a superactivated charcoal on the toxic effects of aflatoxin or T-2 toxin in growing broilers. Poult Sci 76,1205-1211

Elfellah MS, Akhter MH, Khan MT (1984) Anti-hyperglycaemic effect of an extract of Myrtus communis in streptozotocin-induced diabetes in mice. J Ethnopharmacol 11, 275-281

Etcheverry M, Nesci A, Barros G, Torres A, Chulze S (1999) Occurrence of Aspergillus section Flavi and aflatoxin B1 in corn genotypes and corn meal in Argentina. Mycopathologia 147, 37-41

Fernandez A, Verde MT, Gascon M, Ramos J, Gomez J, Luco DF, Chavez G (1994) Variations of clinical biochemical parameters of laying hens and broiler chickens fed aflatoxin-containing feed. Avian Pathol 23, 37-47

Harvey RB, Kubena LF, Phillips TD, Huff WE, Corrier DE (1989) Prevention of aflatoxicosis by addition of hydrated sodium calcium aluminosilicate to the diets of growing barrows. Am J Vet Res 50, 416-420

Issa AY, Volate SR, Wargovich MJ (2006) The role of phytochemicals in inhibition of cancer and inflammation: New directions and perspectives. J Food Compos Anal 19, 405-419

Jansen van Rensburg C, Van Rensburg CEJ, Van Ryssen JBJ, Casey NH, Rottinghaus GE (2006) In Vitro and In Vivo Assessment of Humic Acid as an Aflatoxin Binder in Broiler Chickens. Poult Sci 85, 1576-1583

Krishnamurthy YL, Shashikala J (2006) Inhibition of aflatoxin B1 production of Aspergillus flavus, isolated from soybean seeds by certain natural plant products. Lett Appl Microbiol 43, 469-474

Marquardt RR, Frohlich AA (1992) A review of recent advances in understanding ochratoxicosis. J Anim Sci 70, 3968-3988

Mousavizadeh SA, Khosravinia H, Mousavizadeh SAA (2011) The effect of Myrtus communis leaf powder and citric acid levels in the diet on performance of broiler chickens under heat stress. In: Proceedings of the First National Congress of Agricultural Science and new technologies. Zanjan University, 19-21 September, Zanjan, Iran

Sandosskumar R, Karthikeyan M, Mathiyazhagan S, Mohankumar M, Chandrasekar G, Velazhahan R (2007). Inhibition of Aspergillus flavus growth and detoxification of aflatoxin B1 by the medicinal plant zimmu (Allium sativum L. x Allium cepa L.). World J Microbiol Biotechnol 23, 1007-1014

Shotwell OL, Hesseltine CW, Stubblefield RD, Sorenson WG (1966) Production of Aflatoxin on Rice. Appl Environ Microbiol 14, 425-428

Tessari ENC, Oliveira CAF, Cardoso ALSP, Ledoux DR, Rottinghaus GE (2006) Effects of aflatoxin B1 and fumonisin B1 on body weight, antibody titres and histology of broiler chicks. Br Poult Sci 47, 357-364

Verma J, Swain BK, Johri TS (2002) Effect of various levels of aflatoxin and ochratoxin A and combinations thereof on protein and energy utilisation in broilers. J Sci Food Agric 82, 1412-1417

Wild CP, Turner PC (2002) The toxicology of aflatoxins as a basis for public health decisions. Mutagenesis 17, 471-481

Williams JH, Phillips TD, Jolly PE, Stiles JK, Jolly CM, Aggarwal D (2004) Human aflatoxicosis in developing countries: a review of toxicology, exposure, potential health consequences, and interventions. Am J Clin Nutr $80,1106-1122$ 